PERSPECTIVE

https://doi.org/10.1038/s41467-019-09685-x

\title{
Crowd oil not crude oil
}

\author{
Roland Dittmeyer (10) ${ }^{1}$, Michael Klumpp ${ }^{1}$, Paul Kant (10) ${ }^{1,2} \&$ Geoffrey Ozin (1) ${ }^{2}$
}

\begin{abstract}
Climate change represents an existential, global threat to humanity, yet its delocalized nature complicates climate action. Here, the authors propose retrofitting air conditioning units as integrated, scalable, and renewable-powered devices capable of decentralized $\mathrm{CO}_{2}$ conversion and energy democratization.
\end{abstract}

magine the renewable-electricity-powered air conditioning system in your house, apartment or office at work, besides functioning for cooling and heating, being adapted to capture carbon dioxide and water from the air. Imagine the water and carbon dioxide thus collected converted into renewable hydrocarbon fuels using existing technology and thereby creating personalized, localized and distributed, synthetic oil wells (see Fig. 1). As an alternative to legacy fossil fuel, these oil wells can be tapped, shared and stored, with the option for the property owner to receive payment for any excess fed into a renewable oil grid. Envision this model adopted globally and collectively. This could have a significant impact on the carbon dioxide load emitted into the atmosphere while safely storing available renewable electrical energy and heat in the form of high-energy-density chemical fuel, rather than in pressurized underground carbon dioxide reservoirs with a chance of leakage. As an illustration of the greenhouse gas reduction potential and renewable synthetic oil production capacity of the envisioned approach, a preliminary technical analysis for three practical cases, the Frankfurt Fair Tower office building, a typical grocery store and low-energy houses, is reported. This analysis impressively demonstrates that air conditioning systems in place if equipped with the appropriate technology could indeed capture a very significant amount of carbon dioxide. The envisioned model of "crowd oil" from solar refineries, akin to "crowd electricity" from solar panels, enables people to take control and collectively manage global warming and climate change, rather than depending on the fossil power industrial behemoths. The environmental, economic and social consequences of such a distributed renewable oil well technology should contribute to the practical realization of chemical fuels from carbon dioxide as feedstock in a circular sustainable economy of the future.

\section{Need for change}

Georgius Agricola (1494-1555), German mineralogist and metallurgist, was the first to propose that fossil fuels originate from the remains of plants and animals subjected to heat and pressure in the earth's crust over millions of years.

Fossil fuels, our natural energy legacy, that provide around $85 \% 1,2$ of the current global energy supply, are comprised of coal, oil and natural gas. These fuels first powered the Industrial Revolution of 1760-1840 and continue today unabated, despite the transition to renewable forms of energy. Today, approximately half of the earth's crude oil reserves, two thirds of the earth's gas reserves and three quarters of the earth's coal reserves remain underground ${ }^{3}$. At the current rates of consumption, it is projected that the depletion of these reserves will occur within the next decades to centuries ${ }^{1-4}$. However, it may not even take this long for the unabated use of our

\footnotetext{
${ }^{1}$ Institute for Micro Process Engineering (IMVT), Karlsruhe Institute of Technology (KIT), Hermann-von-Helmholtz-Platz 1, Eggenstein-Leopoldshafen 76344 Germany. ${ }^{2}$ Department of Chemistry, University of Toronto, 80 St. George Street, Toronto M5S 3H6, Canada. Correspondence and requests for materials should be addressed to G.O. (email: gozin@chem.utoronto.ca)
} 


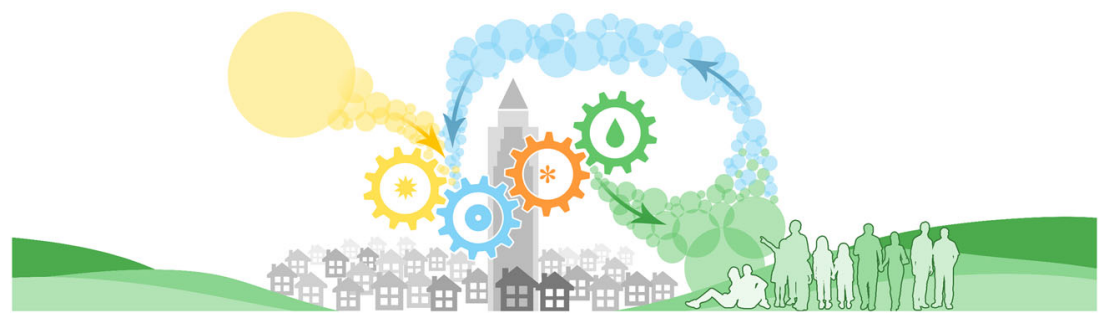

Fig. 1 The vision of crowd oil. Renewable oil wells, a distributed social technology, whereby people in homes, offices and commercial buildings all around the world, collectively harvest renewable electricity and heat and use air conditioning and ventilation systems to capture $\mathrm{CO}_{2}$ and $\mathrm{H}_{2} \mathrm{O}$ from ambient air and convert it, by chemical processes, into renewable synthetic oil-crowd oil-substituting for non-renewable fossil-based oil-a step towards a circular $\mathrm{CO}_{2}$ economy for the benefit of all

fossil fuel inheritance to cause severe health problems of millions of people due to suffocating heat, major damage of the natural and built environment by more frequent flooding, thunderstorms, drought, and other catastrophes, and escape or forced resettlement of the population of whole regions or even countries, all caused by the greenhouse gas effect ${ }^{5-8}$. As recently outlined by the Intergovernmental Panel on Climate Change (IPCC) ${ }^{6}$, only a fast transition of world's economy to an economy with net zero and later in the twenty-first century even net-negative carbon dioxide $\left(\mathrm{CO}_{2}\right)$ emissions will allow humanity to achieve the goals of The Paris Agreement ${ }^{9}$ of 2015 and thus to maintain earth as a planet with limited negative consequences of man-made climate change.

While implementation of renewable solar and wind energy is on the rise and will gradually help ameliorate greenhouse gas emissions, the rate of the transition to a secure global sustainable energy system may not be rapid enough. This is due largely to financial restraints worldwide and lack of consensus by politicians and may not get off the ground because it requires the cooperation and will of so many people in so many countries.

Notwithstanding the challenges of establishing a unified national or international renewable energy policy, myriad science and engineering projects are under development around the world to accelerate and enable the transition from a nonrenewable energy supply to a renewable one. These research projects and industry initiatives focus on many aspects of this endeavour such as new materials and technologies for renewable energy harvesting ${ }^{10-15}$, new topologies and methods for stabilizing power grids ${ }^{12,16-18}$, energy storage ${ }^{16,19,20}$, efficient usage of energy $12,21,22$ and renewable power-based transportation fuels and industrial chemicals mostly from captured carbon dioxide or industrial waste gas streams ${ }^{14,15,23-27}$. The latter involves hydrogen as a potential future fuel but also as an important intermediate for the production of synthetic hydrocarbons.

In practice, these projects can only be realized at a scale capable of significantly influencing the trend of climate change if the largest greenhouse gas-emitting industries agree to adapt to the required changes. However, due to industry's fixation on shortterm financial benefits as main decision criteria, this will likely only happen with government incentives such as cap-and-trade or fee-and-dividend, or if business economics permit and decision makers give approval. In this context, note that fee-and-dividend places a price on all products based on their carbon emissions in production/use, collected and distributed to all citizens equally. The rich will pay more, but the poor will reap benefits, causing people to think twice how to spend their windfall carbon money. It is a contemporary idea where people will decide how to spend their carbon money and decide which companies' products survive, unless they change, as opposed to the cap-and-trade that lets companies decide how to improve.

\section{The vision of "crowd oil"}

Today, there seems to be little public appetite for large-scale $\mathrm{CO}_{2}$ capture and underground storage (CCS) combined with a continued use of fossil energy carriers, mainly due to safety concerns ${ }^{28}$. Even though the public awareness of the need to become a $\mathrm{CO}_{2}$-negative society is on the rise, mainly due to the IPCC reports and its news coverage, the option of CCS using aircaptured $\mathrm{CO}_{2}$ still faces the challenge of not generating a valuable product. To make this happen requires a different approach to provide an economic incentive such as compensation payment financed by taxes or voluntary donations.

Perhaps more likely to gain public support is a project wherein people use renewable electricity and solar thermal or waste heat to collect $\mathrm{CO}_{2}$ in order to recycle it into hydrocarbon fuels in their homes, apartments and offices. The products generated in these decentralized synthetic oil wells could be used to replace conventional fossil fuels or stored for later use. This could be, for example, for power generation in fuel cells or micro gas turbines at times when there is a deficit of renewable power supply, but also as a transportation fuel in the future. People could either act as individuals owning themselves the infrastructure needed for achieving the conversion and use the fuels for their own purposes or sell it to the market. However, they could also align with others to share the infrastructure or parts of it and this way make more efficient use of it. They could also join forces regarding the marketing of the fuels or the financing of investments into new infrastructures to produce such fuels. Existing or new companies could be involved as well, for example, operating processes emitting $\mathrm{CO}_{2}$ (desirably of non-fossil origin or unavoidable) or larger office buildings where $\mathrm{CO}_{2}$ capture could be implemented. These could be connected, for example, to renewable power generation by photovoltaics on the roofs of many single-family homes around as well as to conversion facilities at different sites. Furthermore, collectively or privately owned and operated local power grids and other collection (fuels) and distribution $\left(\mathrm{CO}_{2}\right)$ infrastructures and businesses may be established. Note that depending on the local supply and demand as well as on the available infrastructure very different solutions may emerge, and further that this would put a large number of people in a position where they actively participate in the new energy economy as socalled "prosumers". Today, this concept is limited to power and eventually heat, but in the future it may be applicable to fuels as well.

Local generation of chemical energy carriers is especially attractive in regions with underdeveloped infrastructure. Difficult to reach islands and other remote locations could establish an autonomous supply of all end energy carriers needed avoiding transport over large distances, sometimes with enormous efforts regarding energy and cost.

If massively deployed worldwide, eventually more fuels could be produced along this vision of "crowd oil" than needed in the remaining non-electrifiable segments of transport and industry, 
which could then establish a $\mathrm{CO}_{2}$-negative generation of a synthetic oil reserve for future use. Admittedly, this sounds very futuristic given today's enormous daily consumption of fossil fuels, but it may in the long term provide a valuable alternative to carbonation as a $\mathrm{CO}_{2}$ sink.

The intermittent availability of renewable power from wind turbines and photovoltaics brings about technical and economic challenges which have to be dealt with. Energy storage may help to improve the match between power availability and the capacity for processing it into the desired fuel. Moreover, variations of the availability of $\mathrm{CO}_{2}$ from the capturing system must also be considered. The intermittent supply reduces the capacity utilization and therefore inevitably increases the cost per litre of produced fuel.

Moreover, space requirements and safety issues have to be considered when it comes to implementation of this vision in large cities. The general idea is that local fuel synthesis will target liquid products with a quality as close as possible to drop in standard, and the products of several fuel synthesis units will be collected and upgraded to finished products in small size plants located in commercial zones.

One technical approach to a decentralized synthesis of hydrocarbon fuels based on $\mathrm{CO}_{2}$ which appears to be possible already today involves retrofitting air conditioning (A/C) systems in houses, apartment and office buildings with "existing technology" to capture $\mathrm{CO}_{2}$ and $\mathrm{H}_{2} \mathrm{O}$ from thin air. Electrolysis of $\mathrm{H}_{2} \mathrm{O}$ can produce $\mathrm{H}_{2}$, which combined with captured $\mathrm{CO}_{2}$ produces hydrocarbon fuels via Fischer-Tropsch catalysis or related approaches in mass-produced modular conversion systems, illustrated in Fig. 2.

It is important to realize that companies have commercialized modular technology (see Fig. 3) for capturing $\mathrm{CO}_{2}$ directly from air (DAC) (Climeworks AG, Switzerland; Carbon Engineering, Canada; Skytree, Netherlands), generating $\mathrm{H}_{2}$ electrochemically from $\mathrm{H}_{2} \mathrm{O}$ (Siemens AG, Germany; Hydrogenics, Canada; sunfire $\mathrm{GmbH}$, Germany; Proton On Site, USA) or even synthesis gas by further conversion of $\mathrm{H}_{2}$ with $\mathrm{CO}_{2}$, producing a mixture of $\mathrm{H}_{2}$ and $\mathrm{CO}$ by co-electrolysis of $\mathrm{H}_{2} \mathrm{O}$ and $\mathrm{CO}_{2}$ (sunfire $\mathrm{GmbH}$, Germany), and producing hydrocarbon or oxygenated fuels from $\mathrm{CO}_{2}$ and $\mathrm{H}_{2}$ or synthesis gas catalytically (INERATEC $\mathrm{GmbH}$, Germany; Gensoric GmbH, Germany; Velocys, USA; Primus Green Energy, USA; Carbon Engineering, Canada; Hydrogenics, Canada; Carbon Recycling International, Iceland).

It would be not that difficult technically to add a $\mathrm{CO}_{2}$ capture functionality to an A/C system, and an integrated A/C-DAC unit is expected to show favourable economics. In fact, this has already been patented for lowering the energy requirements for air conditioning in buildings bringing reality to the vision of "crowd oil"29.

Anecdotally, A/C is amongst the most useful inventions of the twentieth century. With continued global warming, the prevalence of $\mathrm{A} / \mathrm{C}$ will likely become more pervasive. Perhaps the use of $\mathrm{A} / \mathrm{C}$ for making hydrocarbon fuels, if adapted globally as suggested, could be A/C 2.0 of the twenty-first century.

Moreover, in the future direct conversion of solar radiation, $\mathrm{CO}_{2}$ and water into hydrocarbon fuels may reach a competitive status compared to the indirect way of first generating power from photovoltaics or concentrated solar energy and then splitting water or $\mathrm{CO}_{2}$ by electrolysis. Focused research on photocatalytic solar fuels is underway worldwide, for example at the Joint Center for Artificial Photosynthesis (JCAP) of the California Institute of Technology in Pasadena, CA, USA ${ }^{11,30,31}$, the Helmholtz Center Berlin, Germany, and the University of Toronto, Canada ${ }^{10,14}$, to name only a few of the many institutions active in this field. Technology for direct solar thermal fuels is being developed at the Swiss Federal Institute of Technology (ETH) in Zürich, Switzerland, the German Aerospace Center (DLR) in Cologne, Germany, and the Weizman Institute of Science in Rechovot, Israel (see e.g.

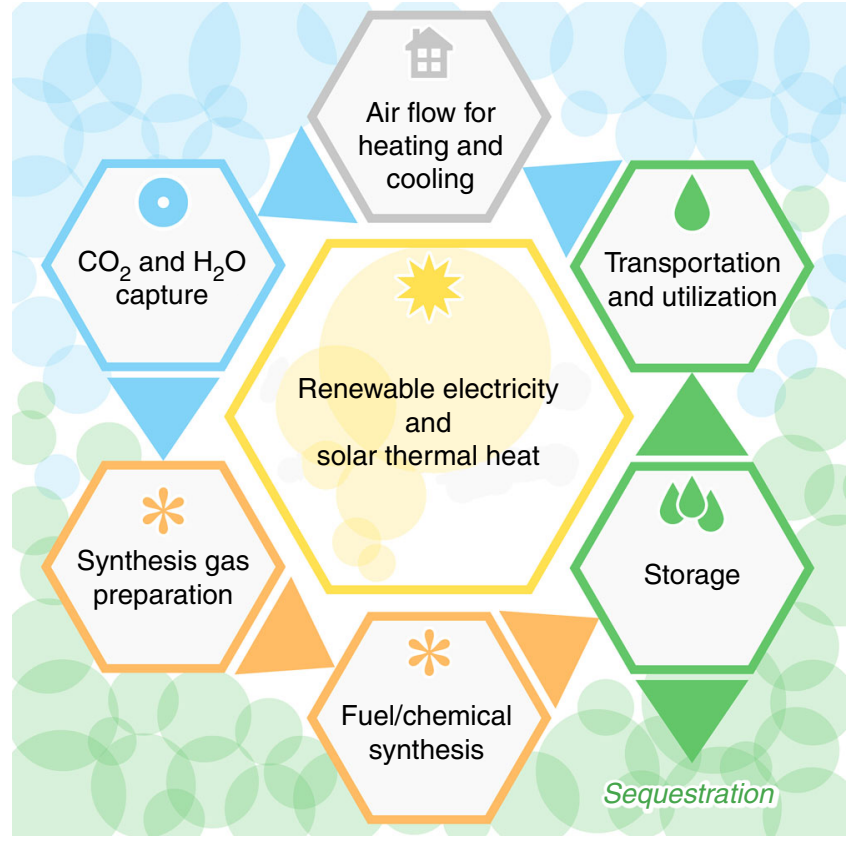

Fig. 2 Envisioned modular, on-site renewable hydrocarbon synthesis system based on $\mathrm{CO}_{2}$ capture from thin air. Counterclockwise from top: Powered by renewable electricity, using modified $\mathrm{A} / \mathrm{C}$ and ventilation systems $\mathrm{CO}_{2}$ and water can be captured from ambient air. Via electro-, photo- or thermocatalytic processes, synthesis gas is generated which is further converted to hydrocarbon fuels by miniaturized chemical processes such as the Fischer-Tropsch synthesis plus integrated upgrading processes (e.g. hydrocracking) allowing to further increase product yield and quality. The synthesized hydrocarbon fuels can be stored and/or transported for further utilization. In case of combustion for mobility or power generation, in this scenario the $\mathrm{CO}_{2}$ emitted is again captured, finally allowing for a closed, net zero carbon cycle, thus, enabling a circular $\mathrm{CO}_{2}$ economy based on hundreds, thousands, and ultimately millions of modular plants. When stored without further utilization even negative emissions can be realized

special issue on Solar Thermochemistry published in Solar Energy $\left.^{13}\right)$. Again, this list is not complete.

The world's population currently stands at 7.6 billion people and is growing at the rate of 83 million people per year ${ }^{32}$. Annual estimates of the $\mathrm{CO}_{2}$ emission load for all countries in the world place the sum total of anthropogenic $\mathrm{CO}_{2}$ emissions in the range of 40 billion metric tons ${ }^{33}$.

Given information on the number of houses, apartment blocks and office buildings in these countries that are, or could be, outfitted with A/C systems, it should be possible to appraise the associated greenhouse gas reduction potential and assess the global capacity to produce, store, distribute, use and recycle renewable hydrocarbon fuels in this way. Moreover, a sustainability assessment based on life cycle analysis and life cycle costing should be capable of providing the necessary insight into the mass, energy and economic flows for such a distributed social technology and sustainability project.

\section{Renewable synthetic oil well-illustrative examples}

In office, commercial and public buildings, a significant volume flow of air is steadily circulated for ventilation and cooling or heating purposes. A typical volumetric exchange rate for office buildings is 5-10 times per hour. Although the concentration of $\mathrm{CO}_{2}$ in the air is low, the absolute amount of $\mathrm{CO}_{2}$ in contact with the A/C device can be substantial. 

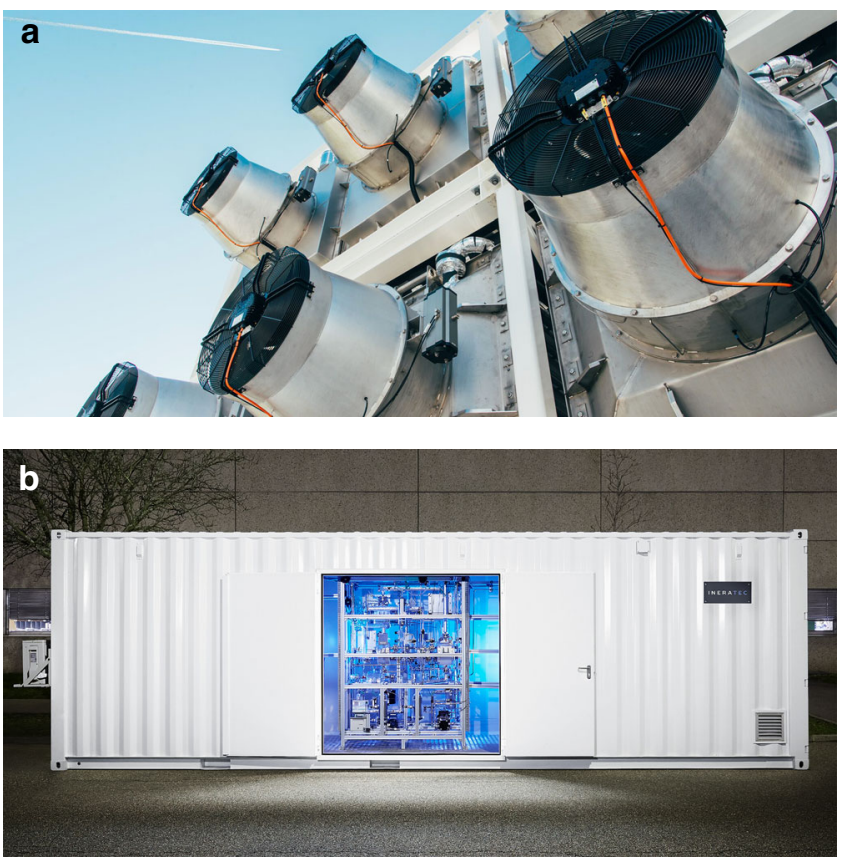

Fig. 3 Modular plants for $\mathrm{CO}_{2}$ capture and conversion. Commercialized modular systems for $\mathrm{CO}_{2}$ capture directly from air (a) and for generation of $\mathrm{H}_{2}$ by $\mathrm{H}_{2} \mathrm{O}$ electrolysis as well as production of hydrocarbon fuels from $\mathrm{CO}_{2}$ and $\mathrm{H}_{2}(\mathbf{b})$ via compact chemical reactor technology. Copyright permission, Climeworks AG and INERATEC GmbH

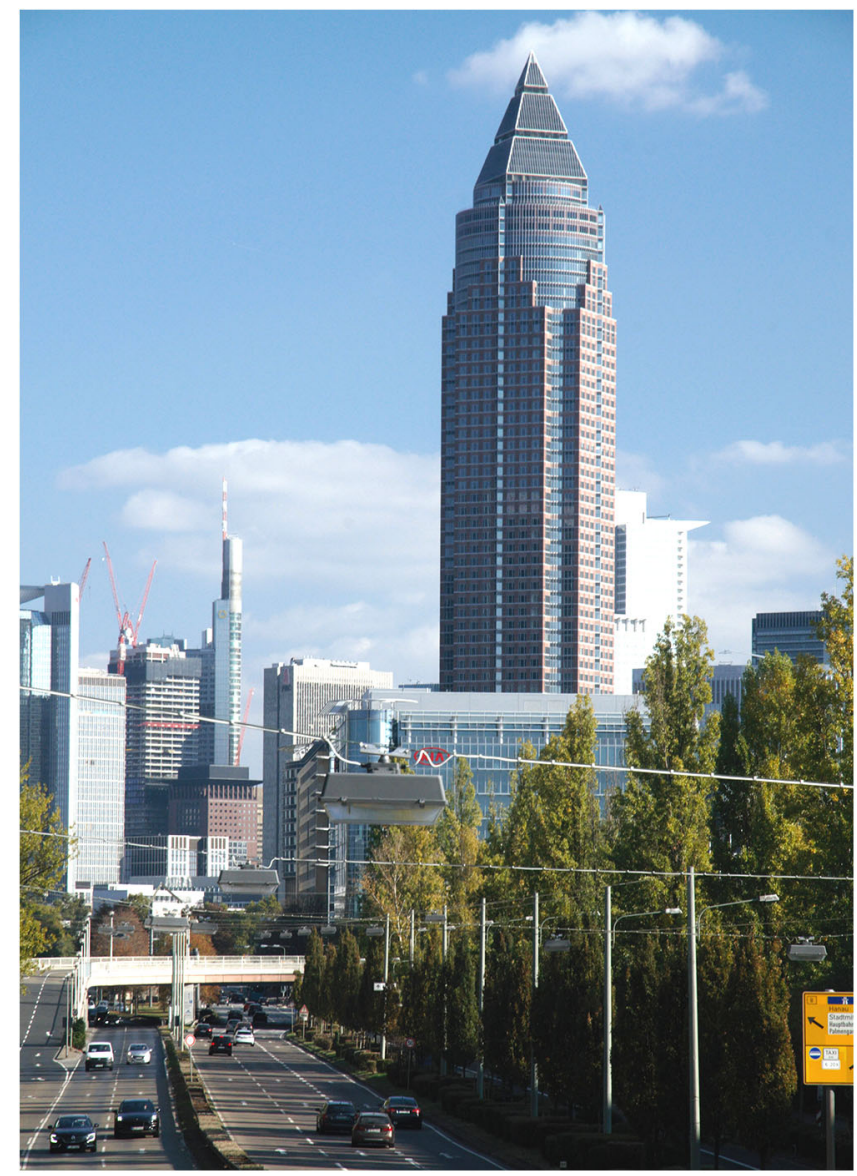

Fig. 4 The Frankfurt Fair Tower. Copyright permission by Gerd Bezner (2018)
As an example, one of the landmark buildings in Frankfurt am Main, Germany, its Fair Tower (see Fig. 4), offers $63,000 \mathrm{~m}^{2}$ of office space. Assuming $3 \mathrm{~m}$ ceiling height yields a total volume of ca. $200,000 \mathrm{~m}^{3}$. Based on the above-mentioned recommended ventilation rate for office buildings, this gives an estimated airflow of $1-2 \mathrm{M} \mathrm{m}^{3} \mathrm{~h}^{-1}$. With $400 \mathrm{ppm} \mathrm{CO}_{2}$ in air ${ }^{33}$, this translates to $0.75-1.5 \mathrm{t} \mathrm{CO}_{2} \mathrm{~h}^{-1}$ ready for capture. According to recently published data for capturing $\mathrm{CO}_{2}$ from air, the energy demand per metric ton of captured $\mathrm{CO}_{2}$ is about 1.43 MWh heat and $0.37 \mathrm{MWh}$ electric power ${ }^{34}$. If combined with an air conditioning system, the demand for additional electric power would be substantially lower because only the additional pressure drop of the $\mathrm{CO}_{2}$ absorber would have to be covered. Thus, mainly an additional heat input of 1.07-2.15 MW would be required if all the $\mathrm{CO}_{2}$ in the contacted air would be recovered. The temperature level needed is $100^{\circ} \mathrm{C}$, which is compatible with solar heat, district heating or reaction heat from the following exothermic fuel synthesis step, e.g., FischerTropsch synthesis.

Pertinent are recent results by the Karlsruhe Institute of Technology (KIT), Climeworks AG, sunfire GmbH, and INERATEC GmbH from the ongoing flagship project "Power-to-X"35 which is part of the so-called "Kopernikus-Initiative" of the German Federal Ministry for Education and Research BMBF to support the Energy Transition. They report a containerized plant integrating $\mathrm{CO}_{2}$ capture from thin air, high-temperature co-electrolysis of $\mathrm{CO}_{2}$ together with steam to produce synthesis gas, and an ultra-compact two-stage fuel synthesis based on the lowtemperature Fischer-Tropsch route and hydrocracking, would produce $344 \mathrm{~kg}$ of liquid hydrocarbon fuels and $24 \mathrm{~kg}$ of wax per metric ton of $\mathrm{CO}_{2}$ captured. Carbon efficiency is high due to the recycling of the gaseous product fraction after the fuel synthesis back into the co-electrolysis. The recycle stream mainly contains unreacted $\mathrm{CO}_{2}, \mathrm{CO}$ and $\mathrm{H}_{2}$ as well as some $\mathrm{CH}_{4}$ and minor amounts of $\mathrm{C}_{2}$ - to $\mathrm{C}_{4}$-hydrocarbons formed in the synthesis as side products. Due to the presence of some inert gas in the feed, a small part of the recycle stream must be discharged. However, even in the worst case studied, per metric ton of $\mathrm{CO}_{2}$ captured, at most $80 \mathrm{~kg}$ of the recycle stream had to be discharged which corresponded to a loss of carbon of only $10.1 \%$. Hence, the carbon efficiency of the integrated process ranges between $89.9 \%$ and close to $100 \%$.

These numbers have been derived from the experimental performance of the individual units together with a process simulation for the integrated process within the detailed engineering of an experimental proof-of-concept plant with a design throughput of $1.25 \mathrm{~kg} \mathrm{~h}^{-1}$ of $\mathrm{CO}_{2}$. Moreover, an overall energy efficiency of $50-60 \%$ has been determined for the integrated process at a scale between $100 \mathrm{~kW}$ and $10 \mathrm{MW}$ for the coelectrolysis unit. Key to the high overall energy efficiency is the utilization of the reaction heat of the Fischer-Tropsch synthesis for providing the steam for the co-electrolysis, which is enabled by the advanced reactor technology used. Based on these data, the amount of $\mathrm{CO}_{2}$ potentially captured by the Frankfurt Fair Tower corresponds to a production rate of liquid hydrocarbon fuels of $250-500 \mathrm{~kg} \mathrm{~h}^{-1}$ or $2000-4000$ metric tons per year, which needs 40-80 microstructured Fischer-Tropsch synthesis modules or 5-10 containers of INERATEC's current design as well as the matching co-electrolysis units. Note that the same calculation assuming the whole available office area in Frankfurt am Main, Germany, which is 11.59 million square metres $^{36}$, would be equipped with this technology results in a tentative potential production rate of 370,000-740,000 metric tons per year. Accordingly, for the five cities with the largest office space in Germany together one obtains $2.4-4.8 \mathrm{M}$ metric tons per year. 
Moreover, considering the $25,000^{36}$ grocery stores of just the three biggest players of the German food retailing industry (with an approx. average area of $1200 \mathrm{~m}^{2} 36$ ), by ventilation (heating and air conditioning) approx. $10,000 \mathrm{~m}^{3} \mathrm{~h}^{-137}$ and for the rooftop condensers of the cooling system for chillers and refrigerators approx. $40,000 \mathrm{~m}^{3} \mathrm{~h}^{-137,38}$, in total approx. $50,000 \mathrm{~m}^{3} \mathrm{~h}^{-1}$ of air circulates within each individual store. This corresponds to a $\mathrm{CO}_{2}$ amount of $40 \mathrm{~kg} \mathrm{~h}^{-1}$ to be captured and converted into $14 \mathrm{~kg} \mathrm{~h}^{-1}$ of liquid hydrocarbon fuels, which can be dealt with in a containerized plant. Having a huge scaling effect provided by tens of thousands of stores, each equipped with a number of synthesis units and the matching co-electrolysis units within one or more compact containers, implies that altogether about 1000 metric tons of $\mathrm{CO}_{2}$ per hour, corresponding to 350 metric tons $\mathrm{CO}_{2}$ per year per store could be captured for processing into hydrocarbon fuels. Impressively, using on-site conversion this would allow provision of $3 \mathrm{M}$ metric tons of hydrocarbon fuels per year, which is about $8 \%$ of Germany's total consumption of diesel of $38.7 \mathrm{M}$ metric tons or $30 \%$ of its total consumption of kerosene of $10 \mathrm{M}$ metric tons ${ }^{39}$.

And what about miniaturized versions? Very small-scale residential $\mathrm{CO}_{2}$ capture and conversion units, like for instance developed in the framework of the willpower-energy project funded by the EU Horizon 2020 Programme and guided by Gensoric $\mathrm{GmbH}^{40}$, could profitably be implemented in low-energy houses, which technically need ventilation to fulfil hygienestandards (humidity and odours), because their highly insulated walls and windows don't allow sufficient air exchange. Especially interesting is the implementation in neighbourhoods with a high share of low-energy houses like for instance the Vauban neighbourhood in Freiburg, Germany (see Fig. 5). For a $70 \mathrm{~m}^{2}$ flat (average for one flat in Vauban ${ }^{41}$ ) with one bathroom, one extra WC, one kitchen and a cellar room a minimum rated airflow of $140 \mathrm{~m}^{3} \mathrm{~h}^{-1}$ can be estimated following the national standard of DIN1946- $6^{42}$. With 5-6 flats per house (average in Vauban ${ }^{41}$ ) and $400 \mathrm{ppm} \mathrm{CO}_{2}$ in ambient air ${ }^{33}$, one building could capture at most $0.5 \mathrm{~kg}$ of $\mathrm{CO}_{2}$ per hour which, converted to hydrocarbons, would yield $4-5 \mathrm{~kg}$ fuel daily. The power required at the electrolysis unit in that scale is in the range of $4-5 \mathrm{~kW}$. System integration, very compact design, low cost and fully automated operation as well as long-term stability and robustness would be imperative. An alternative to individual production units would be a crowd-owned larger production facility in the neighbourhood. All 354 buildings in Vauban ${ }^{41}$ together would for instance capture approx. $200 \mathrm{~kg} \mathrm{~h}^{-1} \mathrm{CO}_{2}$, which converted in one to two containers of INERATEC's current design translates to approx. 620 metric tons of hydrocarbon fuel per year. The 5500 inhabitants in the futuristic and ecological neighbourhood Vauban own $1146 \mathrm{cars}^{41}$. Admittedly this is way less than the average in Germany, where more than 46 million cars ${ }^{43}$ are owned by a bit more than 82 million people ${ }^{32}$. But assuming a consumption of $6 \mathrm{~L}$ hydrocarbon fuel per $100 \mathrm{~km}$, each of the cars in Vauban could drive $11,000 \mathrm{~km}$ per year with the 620 metric tons of fuel synthesized by the crowd's own production facilities, which is close to the average mileage of a car in Germany (approx. 14,000 km per year ${ }^{44}$ ).

These three different examples illustrate the potential of A/C systems equipped with $\mathrm{CO}_{2}$ capture to serve as a carbon source for production of a relevant amount of hydrocarbon fuels. At the same time, one can easily calculate that for substitution of the total current refinery output in Germany of $106 \mathrm{M}$ metric tons ${ }^{39}$ based on air-captured $\mathrm{CO}_{2}$, about $455 \times 10^{12} \mathrm{~m}^{3}$ of air would have to be contacted if all the $\mathrm{CO}_{2}$ could be removed. Given the total surface area of Germany of ca. $358 \times 10^{9} \mathrm{~m}^{2}$ the latter translates into a height of $1300 \mathrm{~m}$ of air all over Germany that would have to be processed during the course of 1 year. This sounds very large, but per day it is approximately $3.5 \mathrm{~m}$ "only" which may appear less threatening. Yet as $100 \%$ removal is certainly unrealistic the actual values would be larger.

One may argue that biomass is a more appropriate source of carbon than thin air given the high dilution of the $\mathrm{CO}_{2}$ in air. However, if the amount of carbon needed for $106 \mathrm{M}$ metric tons of oil products had to be supplied by biomass grown within the German borders, the required volume of air per land area would not be lower. In that case, the growing plants would have to extract the $\mathrm{CO}_{2}$ from the air and only a fraction of that $\mathrm{CO}_{2}$ would be found in the final products.

On a side note, around $302 \times 10^{9} \mathrm{~m}^{3}$ of air per year are passed through the lungs of the whole German population for providing the oxygen to drive their metabolism (derived from $10 \mathrm{~m}^{3}$ per day and person). This is about three orders of magnitude less compared to the volume of air to be processed in order to provide the carbon to fuel their vehicles and produce the chemicals they use.

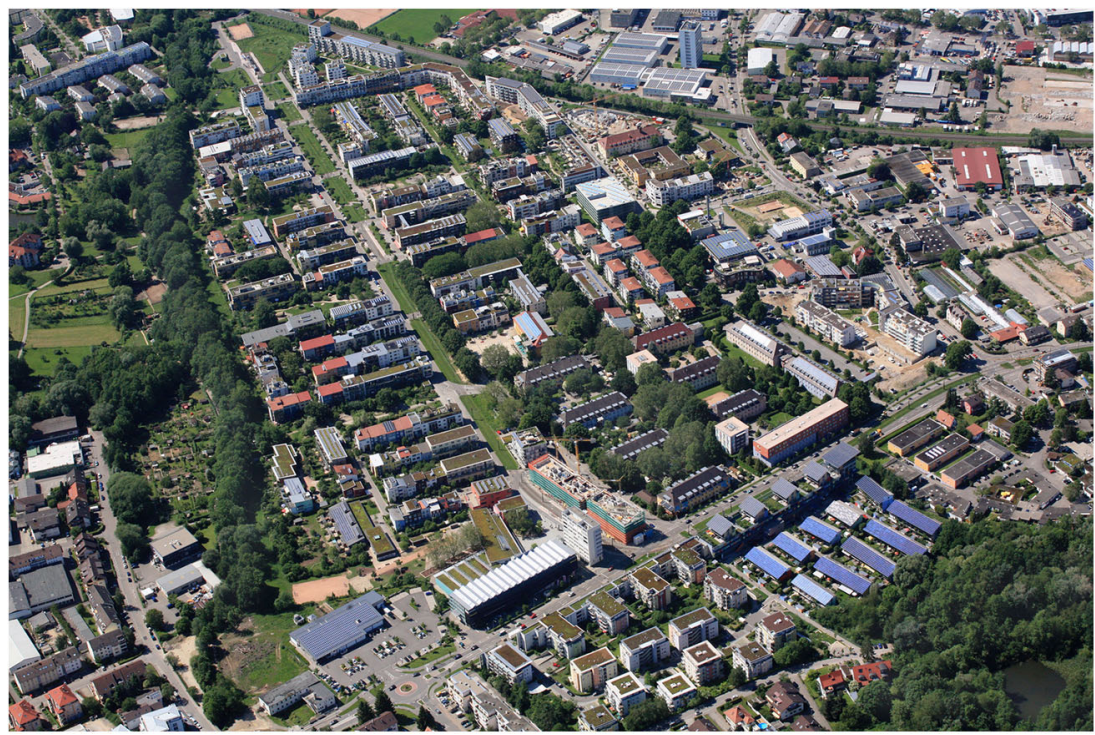

Fig. 5 Aerial view of Vauban neighbourhood in Freiburg, Germany. Copyright permission by Erich Meyer, Hasel|Stadt Freiburg (2012) 
The renewable electrical energy needed to synthesize $106 \mathrm{M}$ metric tons of oil products from $\mathrm{CO}_{2}$ is huge. Assuming a conversion efficiency from electrical energy to fuel of $50 \%$, it would be in the range of 2.800 TWh. Today, about 146 TWh of renewable energy 45 is harvested per year from all the wind turbines and solar panels installed in Germany. There is certainly potential for increasing this value, but the amount of renewable electrical energy required is an enormous challenge. According to statistical data, $9.1 \%$ of all land area in Germany is covered by buildings ${ }^{46}$ and an annual average solar radiation of $1050 \mathrm{kWh} \mathrm{a}^{-1} \mathrm{~m}^{-2}$ is measured ${ }^{47}$. With a panel efficiency of $15 \%$ roughly half of the whole rooftop area would have to be covered by solar panels to generate 2800 TWh per year.

In summary, these numbers tell us that the overall consumption of oil products must be reduced to the minimum needed. Furthermore, air-captured $\mathrm{CO}_{2}$ is a relevant carbon source, which should be considered. And finally, viable mechanisms have to be identified and implemented for quickly building up new infrastructure for decentralized conversion of renewable electrical energy into hydrocarbon fuels.

While the numbers here are for one highly industrialized country mainly for illustration, it is not proposed to strive for energy autonomy on national level both for technical, economic and political reasons. For the case of Germany, there are other countries around in Europe where the potential for wind and solar energy is higher or A/C systems are used more widely, and this equally holds for other continents. Moreover, fair trade of renewable energy and $\mathrm{CO}_{2}$ provides opportunities for economic development and is therefore important for the global economy.

\section{Towards a multifaceted new energy economy}

Depending on the technology, the hydrocarbon fuels produced in small, decentralized plants may need a final workup to match the technical specifications for use. This could be done locally in new, dedicated "mini-refineries" or centrally in some of the existing refineries. Given the high-energy density, liquid hydrocarbons can easily be transported by railways, trucks, and ships. When the capacity of individual wells reaches a threshold, they could also be connected with pipelines. When there is not enough power from renewables over longer periods of time, and electrochemical storage is not sufficient to bridge that time the fuels could be back-converted into electricity in fuel cells or other decentralized power-generation units integrated into an intelligent power grid. Note that this guarantees security of supply but comes at the price of a much lower round-trip efficiency compared to storage in batteries.

Depending on the participation schemes and business models adopted, the fuels could help to satisfy the energy requirements, such as transportation, of the inhabitants of homes, apartments, offices, commercial and public buildings, with any excess fed into storage and distribution systems, in exchange for payments to the property owner, analogous to the feed-in-tariff programmes that kick-started the photovoltaic industry globally.

Once this approach is broadly implemented and when the production of renewable hydrocarbon fuels for transport and chemical industry exceeds its consumption, they can be stored on a large scale, for example in the volumes of depleted oil wells, coalmines and salt caverns. This paradigm envisions an intriguing method of banking synthetic fuels for future energy needs.

On a cautionary note, just as there is not much of a public appetite for enabling massive underground $\mathrm{CO}_{2}$ capture and storage, the same attitude may apply to storing renewable hydrocarbon fuels in empty spaces, such as depleted oil wells.
Safety and environmental issues such as possible contamination of water supplies would certainly have to be investigated.

Since the industrial revolution, energy companies have provided gas, oil, coal and electricity to a passive population and their healthy profits have attracted large investors in the insurance and pension industries. These profits are now under threat by price caps and carbon taxes imposed by governments, and by the continued decrease in the cost of renewable power, exacerbated by the changing behaviour of a more active population towards sustainability.

The generation of power, once the reserve of the fossil-based energy companies, is beginning to shift to people, through "crowd electricity". This is a global project involving the increasing adoption of solar panels and wind turbines, on the roofs of houses and in open fields, with excess electricity either being stored in lithium ion batteries or fed into the electricity grid.

"Crowd oil" could also serve as a global project motivated by the health and well-being of a growing population of global shareholders with a common bond and mutual interest in a sustainable future. This presents an alternative to relying upon government and industrial incentives, often skewed towards delivering financial returns to their corporate executives, directors and shareholders rather than promoting public and environmental health.

Implementation of a grid of renewable synthetic oil wells with private production offers an opportunity to transform an asymmetric global fossil energy resource of "have and have not" countries, with its associated geo-political, geo-social and geoeconomic problems, into a more symmetrical one, wherein all countries can become energy independent in a "people friendly", less complicated circular and sustainable economy.

It is an important part of this vision that the production of renewable fuels from carbon dioxide will be integrated as far as possible into the existing built environment, i.e. limiting the additional land use. This means that buildings populated by humans will act like inhabited technical photosynthesis systems, which is a very intriguing idea given the ever-growing number of human beings on this planet.

\section{Outlook}

The preliminary analysis presented above demonstrates the potential of capturing $\mathrm{CO}_{2}$ from air conditioning systems in buildings, for making a substantial amount of liquid hydrocarbon fuels. While the analysis considers the $\mathrm{CO}_{2}$ reduction potential, carbon efficiency and overall energy efficiency, it does not touch on spatial, or economic metrics for the requisite systems. These have to be obtained from a full techno-economic and life cycle analysis of the entire system. However, with the perspective of mass fabrication of modular intensified units empowered by digitalization and additive manufacturing, the economics as well as the space requirements could well become feasible. Moreover, the long-term reliability and stability of all components of the proposed fully integrated systems have to be addressed in depth by future engineering research in order to prove the feasibility of the concept.

The vision of empowering people with a technology to become energy independent while contributing to a circular economy, a "social energy autarky", gives control to the people to help solve the greenhouse gas, global warming and climate change problems themselves rather than having to rely on the powergenerating industries to rise to the challenge. In order to make this happen, social sciences are needed to investigate how individuals and organizations forming the rather diverse societies around the globe could be motivated to take collective action against global warming and support the implementation of the vision of "crowd oil". As a side note, while less radical, the World Energy Council recently suggested with its report on a 
power-to-X roadmap the establishment of an economic and political framework for the fast worldwide establishment of power-to-X technologies ${ }^{48}$.

\section{Data availability}

All data generated or analysed during this study are included in this published article

Received: 15 November 2018 Accepted: 25 March 2019

Published online: 30 April 2019

\section{References}

1. BP. BP Statistical Review of World Energy. https://on.bp.com/ 2GSwdEa. Accessed 2018-11-08 (BP p.l.c., London, 2018).

2. Koppelaar, R. Rembrandt Koppelaar on World Energy Consumption 1830-2010. https://deepresource.wordpress.com/2012/02/18/rembrandtkoppelaar-on-world-energy-consumption/. Accessed 2019-01-25 (2012).

3. Andruleit, H. et al. Energiestudie 2016 (Bundesanstalt für Geowissenschaften und Rohstoffe BGR, Hannover, 2016).

4. Ritchie, H. \& Roser, M. Fossil fuels. https://ourworldindata.org/fossil-fuels. Accessed 2018-10-07 (2018).

5. Clark, P. U. et al. Consequences of twenty-first-century policy for multimillennial climate and sea-level change. Nat. Clim. Change 6, 360-369 (2016).

6. Allen, M. et al. Global Warming of $1.5^{\circ} \mathrm{C}$ (Intergovernmental Panel on Climate Change (IPCC), 2018).

Ninety-one scientists from 40 member states of the United Nations state that limiting global warming to $1.5^{\circ} \mathrm{C}$ is still possible and highly desirable but needs fast and significant reduction of global anthropogenic $\mathrm{CO}_{2}$ emissions.

7. Carleton, T. A. \& Hsiang, S. M. Social and economic impacts of climate. Science (New York, N.Y.) 353, https://doi.org/10.1126/science.aad9837 (2016).

8. Kim, K.-H., Kabir, E. \& Ara Jahan, S. A review of the consequences of global climate change on human health. J. Environ. Sci. Health C Environ. Carcinog. Ecotoxicol. Rev. 32, 299-318 (2014)

9. United Nations. Paris Agreement. https://bit.ly/2EVSoXT. Accessed 2018-1108 (United Nations, Paris, 2015).

10. University of Toronto. Solar Fuels Cluster. http://www.solarfuels.utoronto.ca/. Accessed 2018-10-07 (2018).

11. California Institute of Technology. Joint Centre for Artificial Photosynthesis. https://solarfuelshub.org. Accessed 2018-10-17 (2018).

12. Massachusetts Institute of Technology. MIT Energy Initiative. http://energy. mit.edu/. Accessed 2018-10-17 (2018).

13. Steinfeld, A., Epstein, M. \& Gonzalez-Aguilar, J. (eds) Advances in Solar Thermochemistry. Solar Energy, Vol. 156 (Elsevier Ltd., Oxford, 2017).

14. Li, Y. F. et al. Pd@HyWO3-x nanowires efficiently catalyze the CO2 heterogeneous reduction reaction with a pronounced light effect. ACS Appl. Mater. Interfaces, https://doi.org/10.1021/acsami.8b04982 (2018).

15. Tu, W., Zhou, Y. \& Zou, Z. Photocatalytic conversion of $\mathrm{CO} 2$ into renewable hydrocarbon fuels: state-of-the-art accomplishment, challenges, and prospects. Adv. Mater. Deerfield. 26, 4607-4626 (2014).

16. Tesla Inc. Tesla Energy. https://www.tesla.com/energy. Accessed 2018-10-17 (2018).

17. Mehrasa, M. et al. Synchronous resonant control technique to address power grid instability problems due to high renewables penetration. Energies 11 , 2469 (2018)

18. Bollen, M. H. J. \& Rönnberg, S. K. Hosting capacity of the power grid for renewable electricity production and new large consumption equipment. Energies 10, 1325 (2017).

19. Helmholtz Institute Ulm. Research. http://www.hiu-batteries.de/batteryresearch-center-in-germany/research/. Accessed 2018-10-17 (2018).

20. Chen, Z. et al. MnPO4-coated $\mathrm{Li}(\mathrm{Ni} 0.4 \mathrm{Co} 0.2 \mathrm{Mn} 0.4) \mathrm{O} 2$ for lithium-ion batteries with outstanding cycling stability and enhanced lithiation kinetics. Adv. Energy Mater. 8, 1801573 (2018).

21. Toyota Motor Corporation. Fuel cell vehicle. https://www.toyota-global.com/ innovation/environmental_technology/fuelcell_vehicle/. Accessed 2018-10-17 (2018).

22. Hagen, A. \& Hendriksen, P. V. Progress of SOFC/SOEC development at DTU Energy. From materials to systems. ECS Trans. 78, 145-153 (2017).

23. Ineratec $\mathrm{GmbH}$. Innovative chemical reactor technology. https://ineratec.de/? lang=en. Accessed 2018-10-17 (2018).

24. Karlsruhe Institut of Technology. Bioliq. https://www.bioliq.de/english/index. php. Accessed 2018-10-07 (2018).
25. Audi AG. Audi g-tron. https://www.audi.de/de/brand/de/neu-angetrieben/gtron.html. Accessed 2018-10-17 (2018).

26. Jia, J. et al. Solar water splitting by photovoltaic-electrolysis with a solar-tohydrogen efficiency over 30. Nat. Commun. 7, 13237 (2016).

27. Neațu, S., Maciá-Agulló, J. A. \& Garcia, H. Solar light photocatalytic $\mathrm{CO}_{2}$ reduction: general considerations and selected bench-mark photocatalysts. Int J. Mol. Sci. 15, 5246-5262 (2014).

28. L'Orange Seigo, S., Dohle, S. \& Siegrist, M. Public perception of carbon carpture and storage (CCS): a review. Renew. Sust. Energ. Rev. 38, 848-863 (2014).

29. Wurzbacher, L. A. \& Gebald, C. Distributed building-integrated carbon dioxide extraction system reducing fresh air requirements. European Patent (2013). Combining $\mathrm{CO}_{2}$ capturing units with air conditioning systems is technically feasible and even has beneficial effects on the energy consumption of the overall ventilation system.

30. Yang, J. et al. A multifunctional biphasic water splitting catalyst tailored for integration with high-performance semiconductor photoanodes. Nat. Mater. 16, 335-341 (2017).

31. Cheng, W.-H. et al. Monolithic photoelectrochemical device for direct water splitting with 19\% efficiency. ACS Energy Lett. 3, 1795-1800 (2018).

32. United Nations. World Population Prospects. Key Findings \& Advance Tables. https://bit.ly/2LyHWuc. Accessed 2018-11-08 (United Nations, Department of Economic and Social Affairs, Population Division, New York, 2017).

33. Le Quéré, C. et al. Global carbon budget 2017. Earth Syst. Sci. Data 10, 405-448 (2018)

34. Keith, D. W., Holmes, G., St. Angelo, D. \& Heidel, K. A process for capturing CO2 from the atmosphere. Joule 2, 1573-1594 (2018).

35. Federal Ministry of Education and Research. The P2X Kopernikus project. https://www.kopernikus-projekte.de/en/projects/power2x. Accessed 2018-1006 (2018).

36. Statista GmbH. Statista-Das Statistik-Portal. https://de.statista.com/. Accessed 2018-11-08 (2018).

37. Mylona, Z., Kolokotroni, M., Tsamos, K. M. \& Tassou, S. A. Comparative analysis on the energy use and environmental impact of different refrigeration systems for frozen food supermarket application. Energy Procedia 123, 121-130 (2017).

38. Mylona, Z., Kolokotroni, M. \& Tassou, S. A. Coupling night ventilative and active cooling to reduce energy use in supermarkets with high refrigeration loads. Energ. Buildings 171, 26-39 (2018).

39. Jahresbericht 2018. https://bit.ly/2tM9y6q. Accessed 2018-11-08 (Mineralölwirtschaftsverband e.V., Berlin, 2018).

40. Gensoric GmbH. Willpower energy. Make your own fuel from $\mathrm{CO} 2$ @ home. https://willpower-energy.eu/index.php/de/. Accessed 2018-11-07 (2018).

41. Willmann, Th. Statistisches Jahrbuch Freiburg (Amt für Bürgerservice und Informationsverarbeitung der Stadt Freiburg im Breisgau, Freiburg im Breisgau, 2017).

42. DIN Deutsches Institut für Normung e.V. Ventilation and Air Conditioning-Part 6: Ventilation for Residential Buildings-General Requirements, requirements for measurements, performance and labeling, delivery/acceptance (certification) and maintenance ICS 91.140.30 (Beuth Verlag GmbH, Berlin, 2009).

43. Der Fahrzeugbestand im Überblick am 1. January 2018. (ZFZR) https://bit.ly/2FMkCXy. Accessed 2018-11-08 (Kraftfahrt-Bundesamt, Flensburg, 2018).

44. Erneut mehr Gesamtkilometer bei geringerer Jahresfahrleistung je Fahrzeug. Kraftverkehrsstatistik. https://bit.ly/2WFR5We. Accessed 2018-11-08 (Kraftfahrt-Bundesamt, Flensburg, 2017).

45. Statistisches Bundesamt. Gross electricity production in Germany. https://www.destatis.de/EN/FactsFigures/EconomicSectors/Energy/ Production/Tables/GrossElectricityProduction.html. Accessed 2018-11-05 (2018).

46. Bodenfläche nach Art der tatsächlichen Nutzung. https://bit.ly/2TNoiNL. Accessed 2018-11-08 (Statistisches Bundesamt, Wiesbaden, 2016).

47. Deutscher Wetterdienst. Solar radiation-solar energy. https://www.dwd.de/EN/ourservices/solarenergy/solarenergie.html. Accessed 2018-11-05 (2014).

48. Perner, J. \& Bothe, D. International Aspects of a Power-to-X Roadmap (Weltenergierat Deutschland, Berlin, 2018).

Power-to-X is an essential part of the global transformation of the energy systems. Long-term, a global Power-to-X market can reach a very substantial dimension-with corresponding investment needs.

\section{Author contributions}

R.D. developed the basic approach and the example of office buildings and led the quantitative assessment. G.O. prepared the first draft of the manuscript and took the lead on language and style. M.K. contributed the grocery store example and developed the 
graphics in Figs. 1 and 2. P.K. provided the low-energy house example and the majority of the references.

\section{Additional information}

Competing interests: The authors declare no competing interests.

Reprints and permission information is available online at http://npg.nature.com/ reprintsandpermissions/

Journal peer review information: Nature Communications thanks Christoph Kiener and the other anonymous reviewer(s) for their contribution to the peer review of this work.

Publisher's note: Springer Nature remains neutral with regard to jurisdictional claims in published maps and institutional affiliations. (c) Open Access This article is licensed under a Creative Commons Attribution 4.0 International License, which permits use, sharing, adaptation, distribution and reproduction in any medium or format, as long as you give appropriate credit to the original author(s) and the source, provide a link to the Creative Commons license, and indicate if changes were made. The images or other third party material in this article are included in the article's Creative Commons license, unless indicated otherwise in a credit line to the material. If material is not included in the article's Creative Commons license and your intended use is not permitted by statutory regulation or exceeds the permitted use, you will need to obtain permission directly from the copyright holder. To view a copy of this license, visit http://creativecommons.org/ licenses/by/4.0/.

(C) The Author(s) 2019 